\title{
THE SECOND STAGE SANATION OF THE LEFT SIDE OF THE BAJINA BASTA DAM
}

\author{
Vicko Letica ${ }^{1}$ \\ Vladimir Danilovic ${ }^{2}$
}

UDK: 627.824.7(497.11)

DOI: $10.14415 /$ konferencijaGFS2021.22

Summary: The Bajina Basta Dam is a hollow gravity dam. It was completed in 1966. In the previous period, due to the occurrence of cracked systems, the Project to repair the left side of the dam was made in 1992. The first phase of rehabilitation was completed in 2006. However, tangential displacements do not have a tendency of stopping. For that particular reason, an additional analysis of the problem of the dam was performed. The second phase of repair refers to blocks No.19 and No.20.

Keywords: hollow gravity dam, repair

\section{INTRODUCTION}

Bajina Basta system of hydropower plants is located in the middle part of the course of Drina River, at about $15 \mathrm{~km}$ upstream from Bajina Basta town. The first HP Bajina Basta, containing four generating units totalling $340 \mathrm{MW}$ of installed power, constructed and put into operation from 1966-1968. The other RHP Bajina Basta (pumping storage type - reversible power plant), equipped with two units, put into operation in 1983. The Bajina Basta Dam is a hollow gravity dam, was designed by Energoprojekt Co. and constructed by Hidroteh $\neg$ nika Co. The dam height is $90.50 \mathrm{~m}$, and the crest length is $461.00 \mathrm{~m}$. The non-overflow sections and powerhouse are located at the right dam half, while the overflow sections and the stilling basin are at the left half. The spillway with five passes, controlled by radial gates of 15.50/14.50 $\mathrm{m}$, is located on the dam crest. Four bottom outlets with diameters of $2.60 \mathrm{~m}$, are located in the hollow gravity elements of the spillway sec $\neg$ tions. The dam is divided by expansion joints into 24 blocks. All the blocks, except lateral sections, have two buttress walls, except block No.21 having only single one. The dam structural elements are con $\neg$ structed of $30 \mathrm{MPa}$ class concrete.

A major part of the dam is founded on Palaeozoic rocks of argil $\neg$ laceous schist and sandstone. The Paleozoic rocks have formed an anticline dipping into both abutments. The left dam abutment is founded on melaphyre volcanic rocks, which is a much more rigid rock than the underlying shales.

\footnotetext{
${ }^{1}$ Mr.dipl.gradj.inž., Beograd BRANE-HPP-WTP. d.o.o office@brane-hpp-wtp.com

${ }^{2}$ Dipl.gradj.inž., Bajina Basta Drinsko Limske hidroelektrane-Bajina Basta
} 


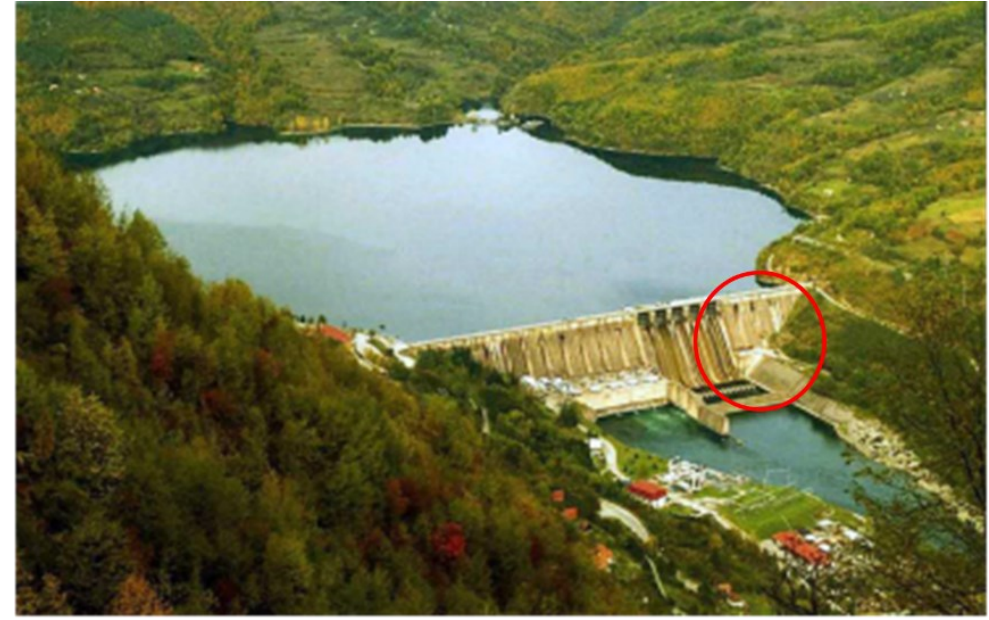

Figure 1. Repair location

\section{PREVIOUS PROJECT AND REPAIRS}

The cracks in the dam buttress walls have appeared in the blocks No.20 and No.21 of the left abutment and were observed during 1987. In the block No.21, the main crack has the widest opening at the foundation zone and the crack path follows the trajectory of the maximum tensile stress. The cracks are extended through the entire block section. The cracks in block No.20 are located on both buttress walls.

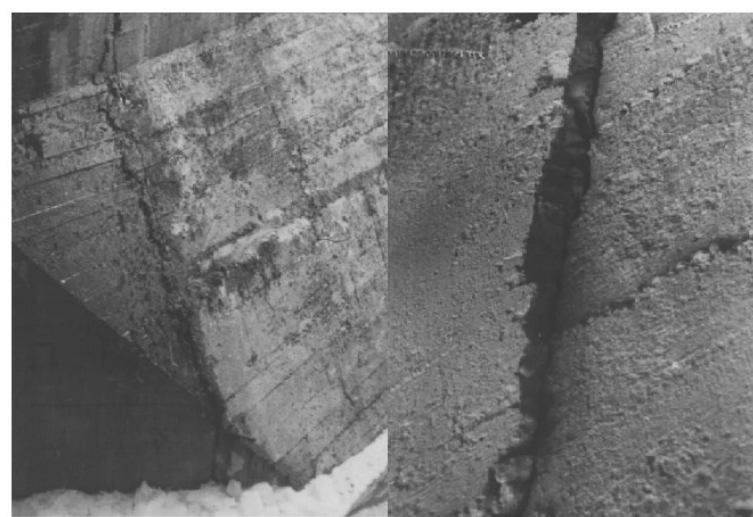

Figure 2. Cracks

Unlike vertical and radial displacements, tangential displacements had an unexpected direction, what is perpendicular to the direction of the river. The dam foundation displacements towards the left bank are observed by geodetic surveys points on the crown and on the downstream face of the dam. This displacements process was quasi-linear and can be estimated as approximately annual increment of about $1.40 \mathrm{~mm}$. 
Contemporary achievements in civil engineering 22-23. April 2021. Subotica, SERBIA

A detailed analysis of the available data was performed in the period 1990-1992, with the basic assumptions being verified by means of numerical models. The projects were based on the analysis of the phenomenon of crack generation and on repair methods. Based on all analyses and calculations, the following conclusions were drawn:

- It was concluded that the cracking causes cannot be the usual loads combined with temperature and heat effects. The fact that no cracks have occurred in the central blocks, whose height and length are greater than the analysed ones.

- Rock displacements are transmitted to the dam in lateral direction. The primary displacement of the foundation strata is constrained by the dam acting, which is in this case, a strut. The left abutment is founded on melaphyre, which is a much more rigid rock than the underlying shales.

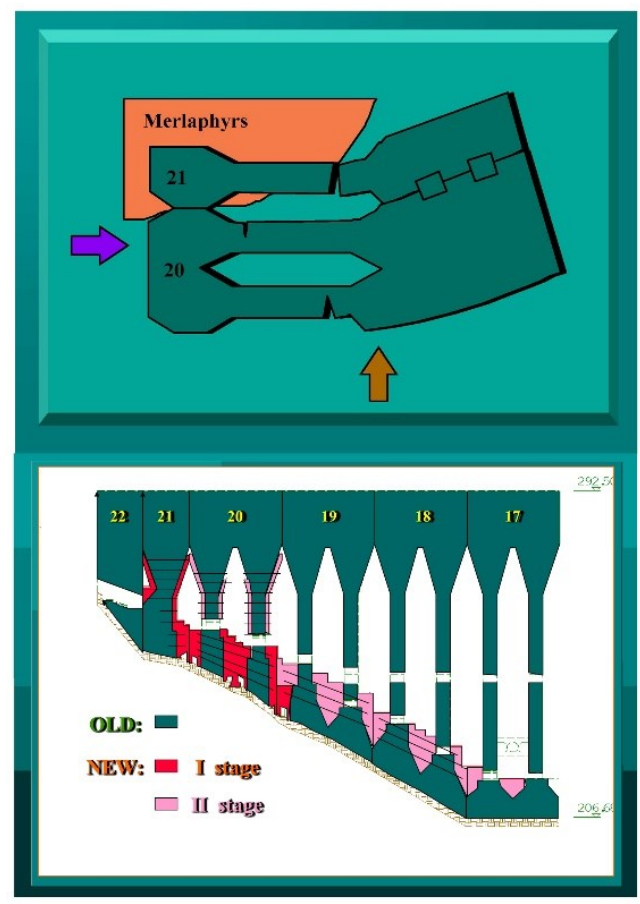

Figure 3. Deformation model and Stages of the sanation

- Likewise, the joint action of the three lateral dam blocks, connected at their downstream ends, causes block bending during horizontal displacements. The left dam abutment supported by the degraded zone of the Palaeozoic and melaphyre rocks contact, in asymmetrical position to the dam axis, is in unfavourable condition. Melaphyre is, unfortunately, located eccentrically with respect to the dam axis. It is clear that under such conditions these movements must cause lateral bending of the dam blocks.

- The stability analyses of full hydrostatic pressure and possible seismic loading case showed considerable differences of the stability coefficients. In this 
particular case, it is clear that the possibility of force transmission exists due to different block displacements.

- That tangential displacements do not have a tendency of stopping but however they have a quasi-continuous increase.

- By analysing possible further spreading of cracks in the dam, it has been ascertained that there is a chance of formation of a kinetic mechanism, whose displacements could endanger the stability of the left abutment blocks and, consequently, the stability of the whole dam.

A solution of the sanction has been adopted which accepts and reduces to the minimum the effects which causing the cracks. Filling of the blocks bottom zones with mass concrete is applied. The new concrete is joined with the old to form a rigid beam. This composite beam is made with pre-stressed cables and grouting of the joints between old and new concrete. The homogeneous beam formed is intended to receive future displacement influences equal to the maximum observed so far. Mass concrete continuous fill reduces the eccentric interaction between blocks. Each block bending is received by the formed composite beams. Finally, the possibility of relative movement between adjacent blocks is reduced. The total concrete and reinforcement bearing capacity is used.

In addition to this filling, the buttress wall of block No.21 is also lined with new concrete, on both sides of the buttress wall, with thickness of $1.00 \mathrm{~m}$, which is as well connected to the old concrete, and which have the function of securing already cracked locations and eliminating the progress of existing cracks under additional loads.

The first stage of repairs is being carried out 2006.

According to the previous Project, it was considered to carry out the repair in three stage. In the first stage, filling of the blocks bottom zones (the interspace between blocks No.20 and No.21) with mass concrete is applied. The block No.21 is also lined with new concrete, on both sides of the buttress wall. In the second phase, filling the space in block No.19 and the cheeks on block No.20 would be performed.

\section{NEW STAGE OF THE SANATION}

The first phase of rehabilitation was completed in 2006. However, tangential displacements do not have a tendency of stopping, but they have a quasi-continuous increase. That reason, an additional analysis of the problem of the left side of the dam was performed.

In order to locate the cracks accurately and to quantify influence intensity to a certain extent, the blocks No.19 and No.18 ware approximated by 3D mathematical models. Numerical calculation of stress and strain was performed by the finite element method (FEM). The geometry of the model is simulated by 3D solid elements with 6885(8193) nodes and 5801(6762) solid elements. Finite element mesh has been approximated with eight nodded three-dimensional iso-parametric solid elements.

In case of hydrostatic load the stability of the model is provided with 582(575) point elements (gap elements) in the base of the foundaments. The influence of hydrostatic loads (reservoir water), are obtained by integration of surface pressure at the joints on the water side. For calculation of vertical influences of the water pressure (uplift) it was assumed 


\section{$8^{\text {th }}$}

Contemporary achievements in civil engineering 22-23. April 2021. Subotica, SERBIA

that usual condition is applied. The dead weight influence is introduced by the program. For the second load, the measured previous displacements in two horizontal directions at three observation targets and vertical displacements in the lower zones of the block were introduced into the analysis as boundary conditions. Linear elastic FEM analysis has been applied.

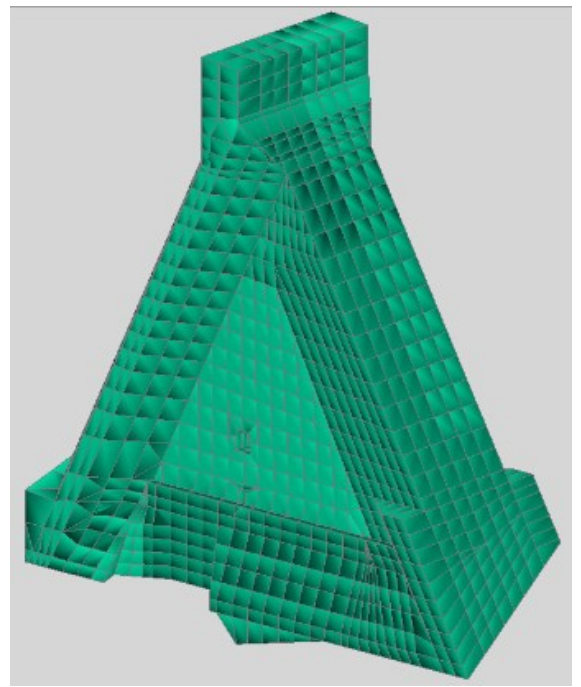

Figure 4. FE model

The analysis of the obtained results shows that there is a coincidence of the maximum tensile stresses with the actual crack locations on the block. According to computation, the maximum tensile stress amounts to $4,02(3,81) \mathrm{MPa}$, which is higher than the tensile strength. Comparing the data obtained from the numerical models with the condition of the dam and with current measurements, it was concluded that it is necessary to continue with the repair, so that the dam could be fully functional and absolutely safe. The second phase of repair refers to sections No.19 and No.20.

The analysis of coupling the pre-tensioned cables for block No.19 was carried out on a plane model where the transversal dimensions approximated with elements of different thickness. In addition to this, calculation of local impacts has been made at places where pre-stressed forces were introduced.

As in the previous stage, filling of the blocks No.19 bottom zones with mass concrete is applied. This composite beam is made with pre-stressed cables and grouting of the joints between old and new concrete. The fill of massive concrete is designed to assure the principal function of uniform transfer of lateral impacts. Furthermore, attention was paid in assuring lateral communication through the dam. Vertical shafts with $\varnothing 2.00 \mathrm{~m}$ have been designed in the massive concrete. These shafts, except their uplift dissipation function, serve as access to the cable ends for coupling and for the grouting inlet-outlet pipes. 


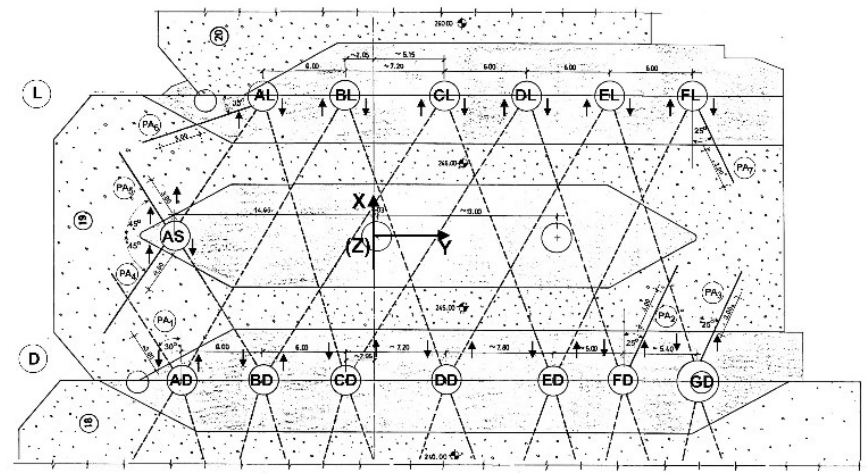

Figure 5. Pre-tensioned cables for block No.19

All lateral bending of block No.19 under the assumption that the reinforcement would accept the temperature change and heat of hydration influences and that the permitted stresses would be admitted there, the designed reinforcement receives about $40 \%$ of lateral bending impacts. Final pre-tension force of $1850 \mathrm{kN}$ per one cable was designed. Anchors and cables were designed in 7 levels.

The new concrete slabs in the higher zones at block No.20 were designed with thickness of $1.00 \mathrm{~m}$ and it extends upward covering the existing fissure. Pre-stressing of block No.21 was carried out by cables with a maximum pre-stressing force of $1500 \mathrm{kN}$ per one cable was designed. The complete procedure should be covered by detailed monitoring and surveying.

For massive concrete and lateral slabs reinforced concrete grade $40 \mathrm{MPa}$ was designed.

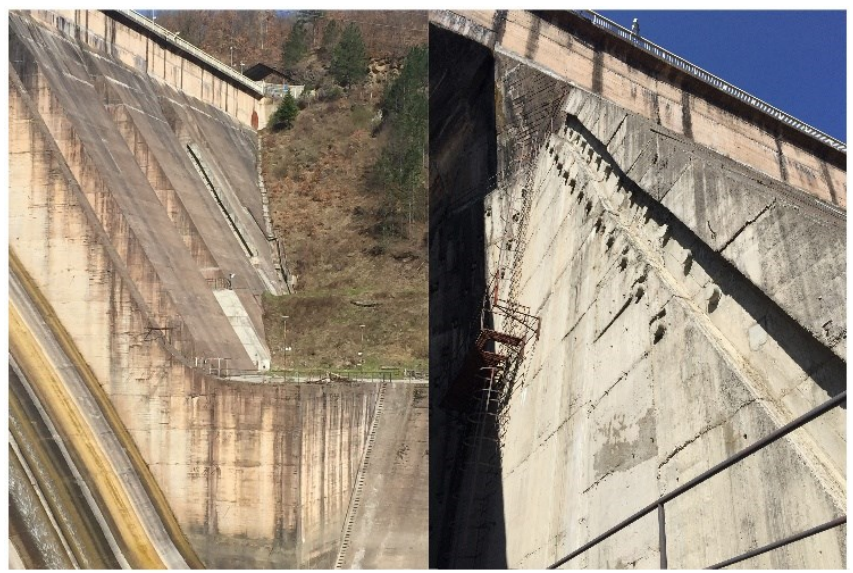

Figure 6. First stage of the sanation-site 


\section{$8^{\text {th }}$}

Contemporary achievements in civil engineering 22-23. April 2021. Subotica, SERBIA

\section{REFERENCES}

[1] V.Letica "Cracks analysis and repair of the Bajina Basta Dam left abutment" 19 ICOLD, Florence 1997. Italy.

[2] V.Letica "Analiza pukotina i sanacija levog boka brane Bajina Bašta", Kongres JDVB Budva 1997.

[3] V.Letica - V.Božić - M.Milošević "Rehabilitation of the Bajina Basta dam left abutment" ICOLD GIGB, Barcelona 1998. Spain.

[4] V.Letica "Sanacija i analiza levog boka brane Bajina Bašta" JDGK, Vrnjačka Banja 1998. Yugoslavia.

[5] A.Božović "Certain problems pertaining to a hollow-gravity dam on compressible foundations", C.15, VII Congress, Rome 1961.

[6] Deo Glavnih i Izvođačkih projekata sistema „Bajina Bašta“.

[7] „EP Hidroinženjering“ a.d. Beograd - Sanacija levog boka brane „Bajina Bašta“ Glavni projekat iz 1992. godine.

[8] „BRANE-HPP-WTP“ d.o.o. Beograd - „Analiza stanja sa statičkom analizom brane i mašinske zgrade HE Bajina Bašta“" maj 2017. godine.

[9] „BRANE-HPP-WTP“ d.o.o. Beograd - „Analiza stanja pukotinskih sistema i dilatacionih spojnica na brani HE Bajina Bašta" februar 2019. godine.

[10] „BRANE-HPP-WTP“ d.o.o. Beograd - „Detaljna analiza stanja pukotinskih sistema na levom boku brane HE Bajina Bašta“ Glavni projekat iz marta 2020. godine. 